\title{
IMPLEMENTASI EVALUASI AFEKTIF \\ PADA PEMBELAJARAN AQIDAH AKHLAK DI MI NU ISLAMIYAH TAHUN PELAJARAN 2021/2022
}

\author{
SRI SURYANTINI \\ MI NU Islamiyah Jetiskapuan Jati Kudus \\ Email : ssuryantini69@gmail.com
}

\begin{abstract}
ABSTRAK
Penelitian ini membahas tentang implementasi evaluasi afektif pada pembelajaran aqidah akhlak. Studi ini membahas permasalahan: 1) Pelaksanaan evaluasi afektif pada pembelajaran Aqidah Akhlak. 2) Kendala dan solusi yang dihadapi dalam pelaksanaan evaluasi afektif pada pembelajaran Aqidah Akhlak. Permasalahan dibahas melalui metode kualitatif dengan studi lapangan (field research) untuk menggali data tentang implementasi evaluasi afektif pada pembelajaran Aqidah Akhlak di MI NU Islamiyah Jetiskapuan Jati Kudus. Penelitian ini menunjukkan bahwa: 1) Pelaksanaan evaluasi afektif pada pembelajaran Aqidah Akhlaq di MI NU Islamiyah Jetiskapuan Jati Kudus dimulai dari memantau perilaku siswa dalam proses pembelajaran, dan dikembangkan penilaiannya ketika ulangan semester. Karena sikap siswa bisa diketahui dalam kehidupan sehari-hari melalui pemantauan. Juga pada evaluasi akhir semester dilakukan penilaian baik atau kurang baiknya sikap atau moral yang selama ini dilakukan oleh siswa. 2) Kendala dalam pelaksanaan evaluasi afektif pada pembelajaran Aqidah Akhlaq tersebut yaitu kurang siapnya siswa, input anak, kurang fokus terhadap materi pembelajaran yang dievaluasikan, sikap siswa yang berbeda-beda, dan tidak ada perubahan tingkah laku setelah adanya evaluasi pemahaman materi pembelajaran Aqidah Akhlak. Adapun solusinya yaitu memberikan semangat kepada siswa, adanya pengarahan untuk menambah dalam membaca materi, pemantauan secara khusus bagi siswa yang kurang fokus agar tidak tertinggal, pemantauan demi meningkatkan kepribadian yang baik, rapat bersama guru dalam menentukan nilai siswa
\end{abstract}

Kata Kunci : Evaluasi Afektif, Aqidah Akhlak

\section{ABSTRACT}

This study discusses the implementation of affective evaluation in learning aqidah morality. This study discusses the following problems: 1) The implementation of affective evaluation in Aqidah Akhlak learning. 2) Constraints and solutions faced in implementing affective evaluation in Aqidah Akhlak learning. Problems are discussed through qualitative methods with field research to explore data on the implementation of affective evaluation in Aqidah Akhlak learning at MI NU Islamiyah Jetiskapuan Jati Kudus. This study shows that: 1) The implementation of affective evaluation in Aqidah Akhlaq learning at MI NU Islamiyah Jetiskapuan Jati Kudus starts from monitoring student behavior in the learning process, and develops its assessment during semester tests. Because students' attitudes can be known in everyday life through monitoring. Also at the end of the semester evaluation, an assessment of the good or bad attitudes or morals that have been carried out by students is also carried out. 2) Obstacles in the implementation of affective evaluation in Aqidah Akhlaq learning, namely the lack of readiness of students, input from children, lack of focus on the evaluated learning materials, different student attitudes, and no change in behavior after the evaluation of understanding of Aqidah Akhlak learning materials. The solution is to encourage students, there are directions to increase reading material, monitoring specifically for students who are less focused so they don't fall behind, monitoring to improve a good personality, meeting with teachers in determining student grades.

Keywords: Affective Evaluation, Aqidah Akhlak 


\section{PENDAHULUAN}

Pendidikan merupakan salah satu strategi untuk meningkatkan kualitas suatu bangsa, oleh karena itu kemajuan pendidik adalah suatu yang menjadi target utama dari sebuah bangsa, maka perhatian khusus pemerintah diberikan pada sektor pendidikan, oleh karena itu ketika bangsa indonesia menjadi negara berdaulat dan modern, yang dilakukan adalah investasi human skill dengan membentuk silabus pendidikan secara sistematis (Surakhmad, dkk. 2013:8).

Menurut UU No. 20 tahun 2003 tentang Sistem Pendidikan Nasional, pendidikan adalah usaha sadar dan terencana untuk mewujudkan suasana belajar dan proses pembelajaran agar peserta didik secara aktif mengembangkan potensi dirinya untuk memiliki kekuatan spiritual keagamaan, pengendalian diri, kepribadian, kecerdasan, akhlak mulia, serta ketrampilan yang diperlukan dirinya, masyarakat, bangsa dan negara.

Pendidikan merupakan (a) proses seseorang mengembangkan kemampuan, sikap, dan bentuk-bentuk tingkah laku lainnya dalam masyarakat tempat dia hidup, (b) proses sosial yang menghadapkan seseorang pada pengaruh lingkungan yang terpilih dan terkontrol (khususnya yang datang dari sekolah), sehingga mereka dapat memperoleh dan mengalami perkembangan kemampuan sosial dan kemampuan individual yang optimum (Sarbini dkk, 2011:20-21).

Belajar bukanlah konsekwensi otomatis dari renungan informasi kedalam benak siswa. Belajar memerlukan keterlibatan mental dan kerja siswa sendiri. Penjelasan dan peragaan semata tidak akan membuahkan hasil belajar yang langgeng hanyalah kegiatan belajar aktif (Silberman, 2009:1).

Pendidikan Akidah Akhlak di Madrasah Ibtidaiyah (MI) sebagai bagian integral dari pendidikan agama, memang bukan satu-satunya faktor yang menentukan dalam pembentukan watak dan kepribadian peserta didik untuk mempraktikkan nilai-nilai keyakinan keagamaan (tauhid) dan akhlaqul karimah dalam kehidupan sehari-hari.

Proses pembelajaran Akidah Akhlak di Madrasah Ibtidaiyah (MI) masih terkesan kurang menarik bagi siswa, hal ini dikarenakan cara guru dalam menyampaikan materi masih cenderung bersifat informatif dan pembelajaran masih berpusat pada guru. Siswa masih menganggap bahwa materi Akidah Akhlak merupakan materi yang membosankan dan banyak teorinya. Selain itu, sebagian besar siswa menganggap bahwa mata pelajaran Akidah Akhlak cukup sulit karena harus menghafal berbagai macam teori. Kurangnya minat siswa terhadap mata pelajaran Akidah Akhlak sangat berpengaruh terhadap rendahnya hasil belajar siswa.

Hasil belajar atau Evaluasi berkaitan erat dengan pengukuran dan penilaian yang pada umumnya diartikan tidak berbeda walaupun pada hakikatnya berbeda satu dengan yang lain. Pengukuran (measurement) adalah proses membandingkan sesuatu melalui suatu kreteria baku (meter, kilogram, takaran dan sebagainya), pengukuran bersifat kuantitatif. Adapun penilaian adalah suatu prosees tarnsformasi dari hasil pengkuran menjadi suatu nilai. Dengan demikian evaluasi meliputi kedua langkah btersebut, yakni mengukur dan menilai dalam rangka pengambilan keputusan. Evaluasi pendidikan memberikan manfaat bagi siswa/peserta pendidikan, pengajar, dan manajemen. Dengan adanya evaluasi, peserta didik dapat mengetahui keberhasilan yang telah dicapai selama mengikuti pendidikan. Saat siswa mendapatkan nilai yang memuaskan, siswa akan memberikan stimulus dan motivasi agar ia lebih meningkatkan presetasi. Saat hasil yang dicapai tidak memuaskan, siswa akan berusaha memperbaiki kegiatan belajar. Disini, sangat diperlukan pemberian stimulus positif dari guru/pengajar agar siswa tidak putus asa. Dari sisi pendidik, hasil evaluasi dapat digunakan sebagai umpan balik untuk menetapkan upaya meningkatkan kualitas pendidikan (Sarbini dkk, 2011:20-21).

Maka dari itu, untuk mengetahui tingkat keberhasilan siswa dalam mempelajari mata pelajaran Aqidah Akhlak haruslah dilakukan pengembangan evaluasi secara rutinitas dengan menilai aspek afektif. Sebab aspek penting dalam pembelajaran Aqidah Akhlak itu, bagaimana mengarahkan sikap atau moral siswa agar dapat melakukan aktifitas atau perilaku yang baik dan mampu mengembangkan dan mengarahkan sikap tersebut menuju akhlaqul karimah. Untuk itu evaluasi atau penilaian afektif dalam pengajaran tidak semata-mata dilakukan terhadap hasil belajar saja, tetapi juga harus dilihat dari sikap kepribadian sehari-hari siswa. 
Permasalahan yang peneliti temukan dalam pelaksanaan penelitian tentang evaluasi afektif di MI NU Islamiyah Jetiskapuan Jati Kudus tidak hanya dilaksanakan pada saat pembelajaran dengan bukti bahwa pelaksanaan evaluasi afektif hanya dinilai pada saat Penilaian Tengah Semester (PTS) dan Penilaian Akhir Semester (PAS). Akan tetapi pelaksanaan evaluasi afektif dilaksanakan di dalam dan di luar pembelajaran, karena pelaksanaan evaluasi afektif harus berorientasi pada perilaku sehari-hari peserta didik sebagai pengamalan nilai-nilai agama Islam.

Adapun masalah sebagai pembahasan pada penelitian ini, (1) bagaimana pelaksanaan evaluasi afektif pada pembelajaran Aqidah Akhlak di MI NU Islkamiyah Jetiskapuan Jati Kudus?, dan (2) Apa saja kendala dan solusi yang dihadapi dalam pelaksanaan evaluasi afektif pada pembelajaran Aqidah Akhlak di MI UN Islamiyah Jetiskapuan Jati Kudus? Dari keseluruhan permasalahan yang ada sebagaimana tersebut di atas penulis ingin meneliti lebih dalam tentang evaluasi pada mata pelajaran Aqidah Akhlak dengan judul "Implementasi Evaluasi Afektif Pada Pembelajaran Aqidah Akhlak di MI NU Islamiyah Jetiskapuan Jati Kudus Tahun Pelajaran 2021/2022”

\section{METODE PENELITIAN}

Pendekatan yang digunakan dalam penelitian ini menggunakan teknis pendekatan "kualitatif". Menurut Bogdan dan Tylor dalam Moleong dan dikutip kembali oleh Margono dalam metodelogi penelitian pendidikan bahwa penelitian kualitatif adalah prosedur penelitian yang menghasilkan data deskriptif berupa kata-kata tertulis atau lisan dari orang-orang dan pelaku yang dapat diamati (Margono, 2014: 36). Sedangkan Kirk dan Miller dalam Moleong (2013:3) mendefinisikan bahwa penelitian kualitatif adalah tradisi tertentu dalam ilmu pengetahuan sosial yang secara fundamental bergantung pada pengamatan pada manusia dalam kawasannya sendiri dan berhubungan dengan orang-orang tersebut dalam bahasanya dan dalam peristilahannya.

Tehnik pengumpulan data dapat dilakukan dalam berbagai setting, berbagai sumber dan berbagai cara. Bila dilihat dari segi cara atau teknik pengumpulan data maka teknik pengumpulan data dapat dilakukan dengan observasi, interview (wawancara), dan dokumentasi. Arifin menjelaskan bahwa observasi adalah suatu proses pengamatan dan pencatatan secara sistematis, logis, objektif, dan rasional mengenai berbagai fenomena, baik dalam situasi yang sebenarnya maupun dalam situasi buatan untuk mencapai tujuan tertentu. Jadi dapat disimpulkan bahwa observasi merupakan teknik yang dilakukan secara langsung dan pencatatan secara otomatis terhadap fenomena yang diselidiki (Arifin, 2017:153). Adapun wawancara adalah suatu bentuk komunikasi verbal jadi semacam percakapan yang bertujuan memperoleh informasi. Bila guru menyanyakan murid tentang keadaan rumah, atau kita menanyakan petani tentang seluk beluk pertanian, itu wawancara. Namun wawancara sebagai alat penelitian lebih sistematis. (Nasution, 2008: 113). Sedangkan dokumentasi yaitu mencari data mengenai hal-hal atau variabel yang berupa catatan, transkrip, buku, surat kabar, majalah prasasti, notulen rapat, agenda dan sebagainya (Fathoni, 2006: 112).

\section{HASIL DAN PEMBAHASAN}

1. Pelaksanaan Evaluasi Afektif Pada Pembelajaran Aqidah Akhlaq di MI NU Islamiyah Jetiskapuan Jati Kudus

Guru dalam pembelajaran berperan membantu peserta didik yang sedang berkembang untuk mempelajari sesuatu yang belum diketahui, membentuk kompetensi dan memahami materi standar yang dipelajari. Untuk peran tersebut guru melakukan hal-hal antara lain: membuat ilustrasi, mendefinisikan, menganalisis, menyintesis, bertanya, merespon, mendengarkan, menciptakan kepercayaan, memberikan pandangan yang bervariasi, menyediakan media untuk mengkaji materi standar, menyesuaikan metode pembelajaran. Sebagai pembimbing, guru harus merumuskan tujuan secara jelas, menetapkan waktu, 
memahami kegiatan belajar, melaksanakan penilaian, bertanggung jawab atas proses pembelajaran baik mental, emosi, kreatifitas, moral, dan spiritual dan peserta didik.

Hasil data wawancara dengan Kepala sekaligus sebagai Guru Aqidah Akhlaq MI NU Islamiyah Jetiskapuan Jati Kudus, beliau menjelaskan bahwa evaluasi afektif atau sikap ini model pengembangannya disamping kami memantau perilaku siswa dalam proses pembelajaran, juga dikembangkan penilaiannya ketika ulangan semester. Karena sikap siswa bisa diketahui dalam kehidupan sehari-hari melalui pemantauan. Juga pada evaluasi akhir semester dilakukan penilaian baik atau kurang baiknya sikap yang selama ini dilakukan oleh siswa.

Model afektif ini detailnya lebih dititik beratkan pada penilaian bidang penyikapan anak terhadap memahami mata pelajaran, khususnya materi yang disampaikan. Bagaimana ia menyikapi dengan rasa, kerena berhubungan dengan afektif. Misal pada materi akhlaq tercela, yaitu berhubungan dengan sikap atau perilaku yang baik dilakukan dan yang tidak baik dilakukan. Selain itu, nilai kepribadian yang dilakukan oleh siswa dalam memahami pengamalan akhlaq atau perilaku sosial siswa, juga ada penialaian dalam hal pengetahuan dan keterampilan siswa

Sedangkan data dari Rif'an selaku Waka Kurikulum di MI NU Islamiyah Jetiskjapuan Jati Kudus menambahkan bahwa Pembelajaran aqidah akhlak yang dilaksanakan ini menekankan bagaimana siswa dapat memahami materi yang berkaitan dengan moral-moral yang harus dipelajari dan dipraktekkan. Karena dengan adanya moral, siswa akan senantiasa menghiasi diri dengan prilaku yang baik sebagai bentuk penerapan dari hasil materi yang telah diketahui oleh siswa. Dan evaluasi model pengembangan afektif yang berjalan selama ini dari evaluasi tertulis atau tugas, karena afektif hubungan dengan rasa atau pemahaman terhadap materi. Selain itu model pengembangannya di rapot ada penilaian tersendiri seperti afektif dan pada pembelajaran akidah akhlaq ini ada catatan khusus dalam menilai perilaku anak sebagai pembentuk karakter siswa.

Dalam hal ini, komponen yang ada dalam penialaian afektif adalah minat, motivasi, sikap dan nilai. Adapun penilaian ranah afektif dilakukan dengan menggunakan instrument penilaian afektif sebagai berikut:

a. Instrumen Sikap, pertanyaan tentang sikap meminta responden menunjukkan perasaan yang positif atau negative terhadap suatu objek, atau suatu kebijakan.

b. Instrumen Nilai, sebagai konsep penting dalam pembentukan kompetensi peserta didik. Pengamatan karakteristik afektif peserta didik dilakukan ditempat dilaksanakannya kegiatan pembelajaran. Untuk mengetahui keadaan afektif peserta didik, perlu ditentukan dulu indikator substansi yang akan diukur, dan pendidik harus mencatat setiap perilaku yang muncul dari peserta didik yang berkaitan dengan indikator tersebut.

c. Instrumen Moral, sebagai tujuan untuk mengetahui moral peserta didik. Moral dapat menyangkut baik-buruknya manusia. Sebutan moral mengacu pada "baik-buruk" seseorang sebagai manusia, yang mengacu pada perilaku.

Dalam bidang afektif ini, kaitannya dengan perubahan-perubahan dalam sikap mental, perasaan dan kesadaran. Ranah afektif yang dikembangkan oleh Krathwohl, Bloom, dan Masia yang dikutip oleh S. Nasution dalam Nurdin dan Usman (2012:107), garis besarnya sebagai berikut:

a. Menerima (memperhatikan) menaruh perhatian, ada kepekaan terhadap adanya kondisi, gejala, keadaan, atau masalah tertentu, dalam bentuk: a) kesadaran, b) kerelaan untuk menerima, dan c) mengarahkan perhatian.

b. Merespon, memberi reaksi terhadap suatu gejala secara terbuka, melakukan sesuatu sebagai respon terhadap gejala itu, dengan cara: a) merespon secara diam-diam, b) bersedia merespon, dan c) merasa kepuasan dalam merespon.

c. Menghargai, memberi penilaian atau kepercayaan kepada suatu gejala yang konsisten, dengan cara: a) menerima suatu nilai, b) mengutamakan suatu nilai, dan c) komitmen terhadap suatu nilai. 
d. Organisasi. Mengembangkan nilai-nilai sebagai suatu system, termasuk hubungan antar nilai-nilai dab tingkat prioritas nilai-nilai itu, dengan cara a) mengkonseptualisasikan nilai, b) mengorganisasi suatu system nilai.

e. Karakteristik suatu nilai atau perangkat nilai-nilai. Mengadakan sintesis dan internalisasi system nilai-nilai dengan cara yang cukup selaras dan mendalam sehingga individu bertindak konsisten dengan nilai-nilai, keyakinan atau cita-cita yang merupakan inti falsafah dan pandangan hidupnya. Hal ini dilakukan dengan memperhatikan: a) pedoman umum, dan b) karakterisasi.

Oleh karena itu penilaian afektif ini tidak dapat dilakukan setiap saat (dalam arti pengukuran formal) karena perubahan tingkah laku siswa tidak dapat berubah sewaktu-waktu. Pengarahan dalam pengubahan sikap seseorang memerlukan waktu yang relatif lama. Demikian juga pengembangan minat dan penghargaan serta nilai-nilai. Pernyataan afektif tidak menuntut jawaban benar atau salah, tetapi jawaban yang khusus tentang dirinya mengenai minat, sikap, dan internalisasi nilai.

Hal ini sesuai aspek akhlaq yang dikaji dalam pembelajaran Aqidah Akhlak ini, bahwa akhlak terhadap makhluk atau sesama disini terdapat berbagai macam bentuknya, diantaranya yaitu, akhlak terhadap diri sendiri, akhlak terhadap rasulullah, akhlak dalam lingkungan keluarga, akhlak terhadap tetangga, dan akhlak keluarga makhluk lain di alam semesta ini.

a) Akhlak terhadap diri sendiri, yaitu sebagai kewajiban moral terhadap dirinya sendiri diantaranya yaitu: memelihara kesucian diri baik jasmani maupun rohani, memelihara kerapian diri, berlaku tenang (tidak terburu-buru), menambah pengetahuan dan membina disiplin pribadi.

b) Akhlak terhadap Rasulullah, yaitu kewajiban untuk menjunjung dan mengagungkan Rasul, yang meliputi memelihara ajaran yang dibawanya, mengikuti sunnahnya mengucapkan salam dan sholawat kepada-Nya.

c) Akhlak terhadap lingkungan keluarga, yang meliputi: akhlak suami kepada istri, akhlak anak kepada orang tua, dan kewajiban dan akhlak anak setelah orang tua wafat (Ya'qub, 2016:141-144).

Melihat dari aspek akhlak, terlihat bahwa berperilaku dan berbicara sopan masuk dalam akhlak terhadap makhluk atau sesama, artinya manusia dalam berbicara haruslah menggunakan bahasa yang sopan, baik dan benar. Selain itu juga, manusia mempunyai perilaku yang baik kepada siapapun. Oleh karena itu evaluasi afektif ini dimulai dengan perubahan sikap melalui pembelajaran Aqidah Akhlak dapat dilakukan sehari-hari agar moral dapat terbentuk dalam diri siswa. Karena tujuan pembelajaran Aqidah Akhlak adalah membantu kepada orang perorangan atau kelompok dengan memberikan pengarahan diri, mengarahkan siswa agar dapat berperilaku baik dan sopan serta memperoleh kebahagiaan hidup serta mewujudkan diri sesuai dengan hakekatnya sebagai manusia yang selaras perkembangan unsur dirinya dan kedudukannya sebagai makhluk Allah. Maka guru pembimbing di sini dapat membantu siswa-siswanya yang telah melanggar aturan madrasah dengan membiasakan memberi pengarahan dan penyuluhan kepada siswa-siswa tersebut.

2. Kendala dan Solusi dalam Pelaksanaan Evaluasi Afektif Pada Pembelajaran Aqidah Akhlaq di MI NU Islamiyah Jetiskapuan Jati Kudus

Evaluasi merupakan instrumen yang harus ada dalam proses pengajaran. Karena dari evaluasi kita dapat mengetahui progresivitas, dan pengembangan serta keberhasilan peserta didik selama melakukan kegiatan belajar dalam jangka waktu tertentu. Evaluasi juga memegang peranan penting dalam mengungkap dan mengetahui tingkat keberhasilan progam pengajaran.

Hasil wawancara dengan Kepala dan guru Aqidah Akhlaq MI NU Islamiyah Jetiskapuan Jati Kudus, bahwa kendala yang dihadapi dalam pelaksanaan model pengembangan evaluasi afektif pada pembelajaran Aqidah Akhlaq di MI NU Islamiyah Jetiskapuan Jati Kudus yaitu: 1) Anak enggan mendengarkan apabila pembelajaran dengan model ceramah, karena kurang antusias. 2) Input anak, atau anak yang kurang dalam berfikir untuk mengubah sikap yang lebih 
baik. 3) Siswa terkadang kurang fokus terhadap materi pembelajaran yang dievaluasikan. 4) Sikap siswa yang berbeda-beda harus menilai sesuai kepribadian masing-masing.

Begitu juga hasil data dari Rif'an selaku Waka Kurikulum MI NU Islamiyah Jetiskapuan Jati Kudus yakni faktor yang menjadi kendala dalam pelaksanaan model pengembangan evaluasi afektif tesebut adalah: 1) Masih ada siswa yang belum siap dalam mengikuti mata pelajaran, yang berdampak mengulur waktu pembelajaran. 2) Kenakalan anak yang berkaitan dengan nilai siswa, akan dikasih nilai yang jelek itu kasihan. 3) Tidak ada perubahan tingkah laku setelah adanya evaluasi pemahaman materi pembelajaran Akidah Akhlak.

Adapun solusinya yang diberikan dari beberapa kendala tersebut antara lain: a) Memberikan semangat kepada siswa agar mempelajari materi yang disampaikan sebagai bahan evaluasi. b) Adanya pengarahan untuk menambah dalam membaca materi, karena masuk dalam penilaian afektif. c) Pemantauan secara khusus bagi siswa yang kurang fokus agar tidak tertinggal dalam memahami materi yang akan dievaluasikan d) Pemantauan dari guru-guru terutama wali kelas untuk mengawasi demi meningkatkan kepribadian yang baik. e) Ketika rapat penegasan itu tidak dari satu atau dua guru yang menilai, tetapi dilakukan dengan rapat bersama guru dalam menentukan nilai siswa.

Tabel 1. Kendala dan Solusi dalam Pelaksanaan Evaluasi Afektif Pada Pembelajaran Aqidah Akhlaq

\begin{tabular}{|l|l|l|}
\hline No & \multicolumn{1}{|c|}{ Kendala } & \multicolumn{1}{|c|}{ Solusi } \\
\hline 1 & $\begin{array}{l}\text { Anak enggan mendengarkan apabila } \\
\text { pembelajaran dengan model } \\
\text { ceramah, karena kurang antusias. }\end{array}$ & $\begin{array}{l}\text { Memberikan semangat kepada siswa agar } \\
\text { mempelajari materi yang disampaikan } \\
\text { sebagai bahan evaluasi. }\end{array}$ \\
\hline 2 & $\begin{array}{l}\text { Input anak, atau anak yang kurang } \\
\text { dalam berfikir untuk mengubah } \\
\text { sikap yang lebih baik. }\end{array}$ & $\begin{array}{l}\text { Pengarahan untuk menambah dalam } \\
\text { membaca materi, karena masuk dalam } \\
\text { penilaian afektif. }\end{array}$ \\
\hline 3 & $\begin{array}{l}\text { Siswa kurang fokus terhadap materi } \\
\text { pembelajaran yang dievaluasikan. }\end{array}$ & $\begin{array}{l}\text { Pemantauan secara khusus bagi siswa } \\
\text { yang kurang fokus agar tidak tertinggal } \\
\text { dalam memahami materi yang akan } \\
\text { dievaluasikan }\end{array}$ \\
\hline 4 & $\begin{array}{l}\text { Sikap siswa yang berbeda-beda } \\
\text { harus menilai sesuai kepribadian } \\
\text { masing-masing. }\end{array}$ & $\begin{array}{l}\text { Pemantauan dari guru-guru terutama wali } \\
\text { kelas untuk mengawasi demi } \\
\text { meningkatkan kepribadian yang baik. }\end{array}$ \\
\hline 5 & $\begin{array}{l}\text { Tidak ada perubahan tingkah laku } \\
\text { setelah adanya evaluasi pemahaman } \\
\text { materi pembelajaran Akidah } \\
\text { Akhlak. }\end{array}$ & $\begin{array}{l}\text { Ketika rapat penegasan itu tidak dari satu } \\
\text { atau dua guru yang menilai, tetapi } \\
\text { dilakukan dengan rapat bersama guru } \\
\text { dalam menentukan nilai siswa }\end{array}$ \\
\hline
\end{tabular}

Dari uraian kendala tersebut, siswa juga perlu berusaha untuk menciptakan kondusifnya pembelajaran dikelas melalui dengan pola belajar siswa, dan pola belajar siswa tersebut juga mempunyai beberapa faktor, faktor-faktor yang mempengaruhi belajar siswa dapat dibedakan menjadi tiga macam, yaitu:

a. Faktor internal siswa, yakni faktor yang berasal dari dalam diri siswa sendiri. Faktor internal siswa meliputi 2 aspek, yaitu:aspek fisiologis (yang bersifat jasmaniyah), dan aspek psikologis (yang bersifat ruhaniyah.

b. Faktor ekternal siswa, yakni faktor yang berasal dari luar diri siswa, seperti faktor internal siswa, faktor eksternal juga terdiri dari dua macam, yaitu: 1) faktor lingkungan sosial : lingkungan sosial sekolah seperti para guru, para staf administrasi dan teman-teman kelas dapat mempengaruhi semangat belajar siswa. 2) faktor lingkungan nonsosial yang 
termasuk adalah gedung sekolah dan tempatnya, rumah tempat tinggal siswa dan letaknya, alat-alat belajar, keadaan cuaca dan waktu belajar yang digunakan siswa.

c. Faktor pendekatan belajar yaitu segala cara atau strategi yang digunakan siswa dalam menunjang efektivitas dan efisiensi proses pembelajaran materi tertentu (Syah, 2010:137138).

Disamping faktor-faktor internal dan eksternal siswa sebagaimana yang telah dipaparkan di atas, faktor pendekatan belajar juga berpengaruh terhadap taraf keberhasilan proses pembelajaran siswa tersebut. Oleh karena itu apabila dalam suatu pelaksanaan pembelajaran terdapat kendala, maka selayaknya dicarikan solusi yang tepat untuk mengatasinya, agar kendala tersebut tidak mengganggu pelaksanaan pembelajaran dalam penilaian afektif.

\section{KESIMPULAN}

Pelaksanaan evaluasi afektif pada pembelajaran Aqidah Akhlaq di MI NU Islamiyah Jetiskapuan Jati Kudus dimulai dari memantau perilaku siswa dalam proses pembelajaran, dan dikembangkan penilaiannya ketika ulangan semester. Karena sikap siswa bisa diketahui dalam kehidupan sehari-hari melalui pemantauan. Juga pada evaluasi akhir semester dilakukan penilaian baik atau kurang baiknya sikap atau moral yang selama ini dilakukan oleh siswa. Pembelajaran aqidah akhlak yang dilaksanakan ini menekankan bagaimana siswa dapat memahami materi yang berkaitan dengan moral-moral yang harus dipelajari dan dipraktekkan. Karena dengan adanya moral, siswa akan senantiasa menghiasi diri dengan prilaku yang baik sebagai bentuk penerapan dari hasil materi yang telah diketahui oleh siswa.

Kendala dalam pelaksanaan evaluasi afektif pada pembelajaran Aqidah Akhlaq tersebut yaitu kurang siapnya siswa, input anak, kurang fokus terhadap materi pembelajaran yang dievaluasikan, sikap siswa yang berbeda-beda, dan tidak ada perubahan tingkah laku setelah adanya evaluasi pemahaman materi pembelajaran Aqidah Akhlak tersebut. Adapun solusinya yaitu memberikan semangat kepada siswa, adanya pengarahan untuk menambah dalam membaca materi, pemantauan secara khusus bagi siswa yang kurang fokus agar tidak tertinggal, pemantauan demi meningkatkan kepribadian yang baik, rapat bersama guru dalam menentukan nilai siswa.

\section{DAFTAR PUSTAKA}

Arifin, Zainal. (2017) Evaluasi Pembelajaran, Prinsip, Tehnik dan Prosedur, Bandung : PT Remaja Rosdakarya.

Arikunto, Suharsimi. (2010). Prosedur Penelitian Suatu Pendekatan Praktik. Jakarta : Rineka Cipta.

Margono, S. (2014). Metodologi Penelitian Pendidikan. Jakarta : Rineka Cipta.

Moleong, Lexy J. (2013). Metode Penelitian Kualitatif. Bandung: PT. Remaja Rosdakarya.

Nasution, S. (2008). Metode Research (Penelitian Ilmiah). Jakarta: Bumi Aksara.

Nurdin, Syafrudin, dan Usman, Basyirudin. (2012) Guru Professional dan Implementasi Kurikulum, Jakarta: Ciputat Press.

Sarbini, Neneng Lina. (2011). Perencanaan Pendidikan. Bandung : Pustaka Setia.

Silberman, Melvin L. (2009). Active Learning, 101 Cara Belajar Siswa Aktif, diterjemahkan oleh Paisal Muttaqin. Bandung: Nusa Media.

Surakhmad, Winarno. (2013). Pengantar Interaksi Belajar Mengajar (Dasar-dasar dan Teknik Metodologi Pengajaran). Bandung: Tarsito.

Syah, Muhibbin. (2010). Psikologi Pendidikan. Bandung: Remaja Rosdakarya. Bandung.

Ya'qub, Hamzah. (2016). Etika Islam Pembinaan Akhlak Akhlakul Karimah. Bandung;Diponegoro. 